\title{
Making Teaching Relevant: Enhancing Students' Self-Efficacy Through Teachers' Enthusiasm for More Active Classroom Engagement
}

\author{
Hany Zaky \\ Correspondence: Hany Zaky, College of Education, Indiana University of Pennsylvania, PA, USA. \\ E-mail: hanyamideast@gmail.com or lnmw@iup.edu
}

Received: June 2, $2020 \quad$ Accepted: June 27, $2020 \quad$ Online Published: June 30, 2020

doi:10.11114/ijce.v3i2.4882 URL: https://doi.org/10.11114/ijce.v3i2.4882

\begin{abstract}
A strong sense of self-efficacy supports human accomplishment. Learners with high assurance in their capacities could approach difficult tasks as challenges to be handled rather than threats to be avoided. Such an outlook fosters those learners' activities' engrossment and their intrinsic interests of the learned contents. Therefore, learners set themselves goals and keep a strong commitment to these designated goals. To face failure, learners heighten and sustain their efforts by attributing this failure to insufficient effort and deficient knowledge and skills which ought to be acquired. To this end, those learners utilize their prior knowledge assurance to overcome the confronted threats.

Concurrently, teachers ought to provide the relevant instruction that empowers their students. Consequently, learners could raise their expectations of the relevance of the perceived cognition and make sense of their world. Make learning relevance deemed a catalyst towards learners' self- efficacy, motivation, and engagement with the learning processes. This article examines the irrevocable relationship between learners' self- efficacy and their learning relevance towards mastery learning and active classroom engagement. The article raises some teaching challenges and suggests some research-based strategies to help teachers appreciate the broad panorama of learning and teaching in classrooms characterized by teaching self-efficacy and enthusiasm.
\end{abstract}

Keywords: self-efficacy- teaching relevance- classroom engagement- motivation

\section{Introduction}

The main goal of school education is to support students to learn for more personal and academic development. The learning beliefs that students bring to classrooms significantly influence the way they respond to the offered teaching experiences. However, these beliefs and learning attitudes are malleable and responsive to the various teaching contents, which encompasses everything from the subject matter, formal curriculum, instructional methods, and materials to the specific set of skills and processes. Recent research provides some insights into how classroom conditions impact students' academic mindsets. Yet, the area needs more research and progressive dialogues due to the rapid changes in the field of pedagogy. During these rapid changes, teachers have a lion share with enhancing their students' learning. Thence, teachers' knowledge and motivation are essential characteristics to secure a thriving educational community.

Teacher's professional expertise and motivational orientations for students' performance are two fundamental constructs for active learning and teaching (Lazowski, \& Hulleman, 2016). These constructs are conceptualized by three central teaching and learning related domains: Self- efficacy, teachers' teaching enthusiasm, and teachers' belief of inclusiveness. For more effective teaching, teachers' motivational orientations are considered the main pillars that could direct students' performance. The process of motivational orientations is related to the psychological dynamics of behavior, monitoring, enthusiasm, self- efficacy, and regulation (Mora et al., 2017). Therefore, teachers could be pleased as students will be more meaningfully engaged in the learning.

\section{Self- Efficacy and Learning}

Self -efficacy is defined as peoples' beliefs about their capacities to achieve a designated performance level for more learning competences. It determines how learners feel, think, motivate, and behave. It is also cognitive, motivational, affective, and processes' selection of those learners in physical and online environments. Self- efficacy enhances human achievement as people approach difficulties with high assurance, considering these difficulties as challenges to be mastered rather than obstacles and threats to be avoided. To this point, learners attribute failure to insufficient effort and knowledge manipulation. They approach threatening situations with assurance to obtain more control over the learning to reduce stress and lower vulnerability to depression throughout their learning experiences. 


\subsection{Sources of Self-Efficacy}

Reports in the literature of self-efficacy indicate that four primary sources can develop people's beliefs about their selfefficacy. First, mastery experience: It is considered the most effective tool to create a sense of efficacy. Success achievements construct a robust belief in one's efficacy, yet failures undermine it (Ross, 2018). Resilient sense of efficacy, though, requires the experience of overcoming obstacles through perseverant effort (Dockter et al. 2017). Second, the vicarious experience: It is the tool to strengthen the self-belief of efficacy through social modals. The process of observing people like oneself raises the observer's belief that they, too, obtain the abilities to master the activities required to succeed. Conversely, observing others's fail despite their high efforts lower the feeling of self- efficacy. Therefore, in any educational context, there is an urgent need for modeling. Modeling is a tool that provides a social standard against which to evaluate one's capabilities (Jones et al., 2016). The impact of modeling on perceived self-efficacy is strongly influenced by perceived similarity to the models. People seek proficient models who possess the competencies to which they hope to have. Through those model's behavior and ways of thinking, competent models transmit knowledge and instill observers.

Social persuasion is the third tool to strengthen people's belief in having what makes them successful. The persuasive boosts in perceived self- efficacy lead people to try hard to develop their skills. However, unrealistic boosts in efficacy are quickly disconfirmed by the disappointing results of one's efforts (Bandura, 2010). So, people who have been persuaded that they lack abilities tend to avoid challenging activities that might create behavioral validation. Thus, teachers need to structure situations for students that could bring success and avoid placing those students in situations where they likely are failure either within online classes or face to face ones. Most students measure their success in terms of their self-improvement in the given tasks. Consequently, their mood affects their efficacy as a positive mood enhances perceived self- efficacy (Bandura, 2010). Reducing stress is the fourth way of modifying self- efficacy. It is the tool to alter learners' negative emotional proclivities during the learning course (Farrington et al., 2012). Overall, students' mastery learning experiences, vicarious experience, students' social learning persuasion, and reducing learning stress strategies are the four main pillars to build students' self- efficacy in various classroom environments.

\section{Self-efficacy Activated Processes}

Much research has been conducted on the influence of self-efficacy on human functioning. These studies highlight four major psychological processes towards high learners' self-efficacy:

\subsection{Cognitive Processes}

Self- efficacy beliefs have a significant impact on the learners' cognitive processes in a variety of ways. Studies indicated that forethought embodying valued goals regulate much human behavior, and self- capacities direct the individual purpose. So, the stronger learners perceive self- efficacy; the higher challengeable goals will be set and followed firmly (Dweck, 2006; Jones, 2018). Studies also reported that most courses of action are primarily organized by thoughts (Bandura, 1986, 1991a, 2010). Therefore, learners' belief in their self-efficacy shapes those learners' anticipatory scenarios. Learners with high self-efficacy could visualize their success in a way providing a positive guide for higher performance (Bandura, 1991 b). However, learners who visualize failure scenarios find lots of difficulties while fighting their self-doubt. The main function of thoughts is to enable learners to predict future events and develop ways to control the activities influencing their performance. Developing these skills needs a specific level of effective cognitive processing of information that contains many uncertainties with the learning progress (Duckwort, 2006). Consequently, learners' regulative rules will be drawn on their knowledge to construct options, integrate predictive factors, test their options, revise their judgments, and modify the opportunities for more regular performance. Thus, to remain a task-oriented, learners need to obtain a high sense of Self-efficacy for more consistency with learning development. Teachers, on the other hand need to consider their students background knowledge. Sometime students have insufficient background knowledge, which makes it difficult for teachers to have those students begin the learning process and be active participants.

\subsection{Motivational Processes}

Previous studies of self-efficacy highlighted the importance of learners' Self-regulation of motivation (Jones, 2017). Learners motivate and guide their actions based on the exercise of forethought as they form a specific belief of what they should do. Those learners set their learning goals and plan courses of designed action to realize valued future performance. The motivation theories are built around three major cognitive motivation forms: Causal attribution, Outcome expectancies, and Cognized goals. Self- efficacy beliefs influence learners' causal attributions of their success or failure of accomplishing their designated learning goals (See Table 1). For example, learners who regard themselves as highly efficacious attribute their failure to insufficient effort, and learners who deem themselves inefficacious attribute their failures to low abilities (Jones et al., 2016). Causal attributions influence motivation, performance, and affective reactions through learners' self-efficacy. Therefore, teachers ought to prepare activities that could build a conceptual base of understanding for students and thereby help them succeed in the selected learning tasks. This preparation step motivate 
learners to desire pursuing the learning and putting forth effort in the process of gaining knowledge.

Table 1. The attribution Theory of Motivation

Locus of control

\begin{tabular}{|c|c|c|}
\hline & Internal & External \\
\hline Stable & Ability & Task difficulty \\
\hline \multicolumn{3}{|l|}{ Stability } \\
\hline Unstable_. & Effort & Luck \\
\hline
\end{tabular}

Through the Expectancy Theory of motivation, motivation is regulated by expectations that a given course of behavior will produce specific outcomes (See Figure 1). However, learners act based on their beliefs regarding what they can do and what they expect to occur (McGinley et al., 2014). For example, learners do not pursue some activities as they deem lacking the capabilities for performing them. However, a large body of research reported that challenging goals enhance motivation (Hall, Jones, \& Hu, 2013). The motivation based on goal setting includes the process of cognitive comparison. Hence, learners could direct their behavior and create incentives to be more persistent toward achieving their designated goals. Learners seek self- satisfaction from fulfilling valued goals (See Figure 2). There are three kinds of self-directed motivation based on goals- influences: Self-satisfaction, Self- dissatisfaction, and Perceived self-efficacy for the attained goals regarding one' s progress. Overall, the fusion of the three self- directed motivations strictly direct learners' selfefficacy either positively or negatively for more consistency with the learning processes.

Self- efficacy contributes to motivation in several ways. It determines the goals learners could set for themselves, the effort those learners could exert and expand, how they persevere in the face of difficulties, and their resilience to the failure experiences (Pajares, 1996; Jones, 2018). Learners who have a strong belief in their capabilities exert more effort to overcome their failure experiences. So steady perseverance contributes to performance achievements. Within the instructional course, teachers could provide their students with assistance to better comprehend the learning contents. 


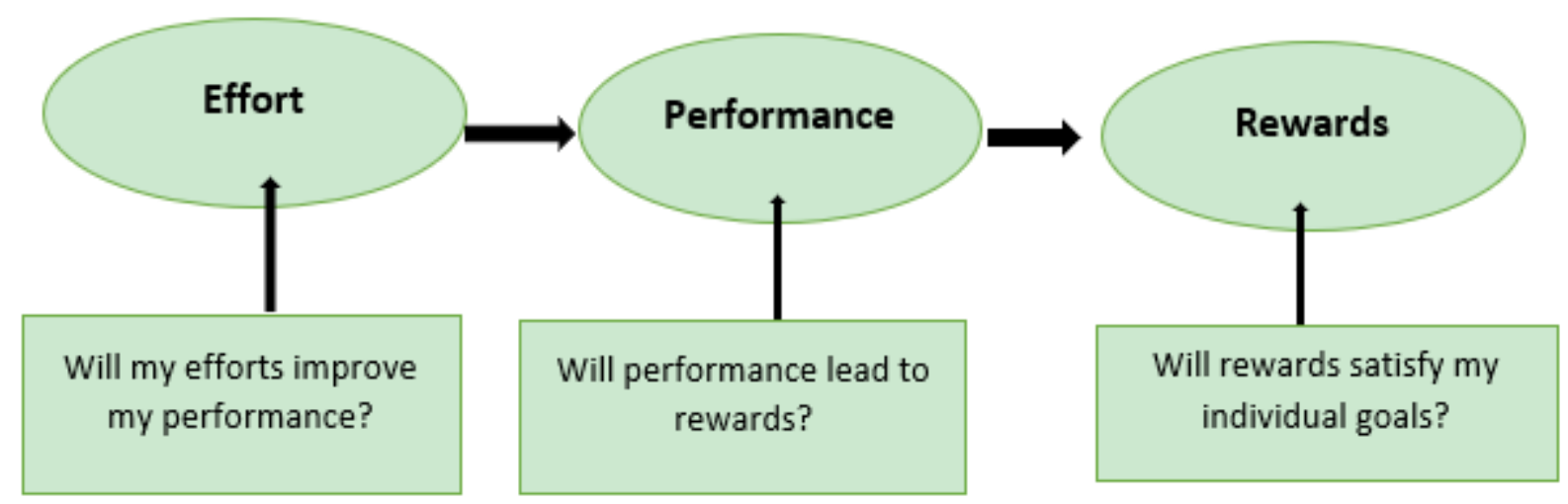

Figure 1. The Expectancy Theory of Motivation

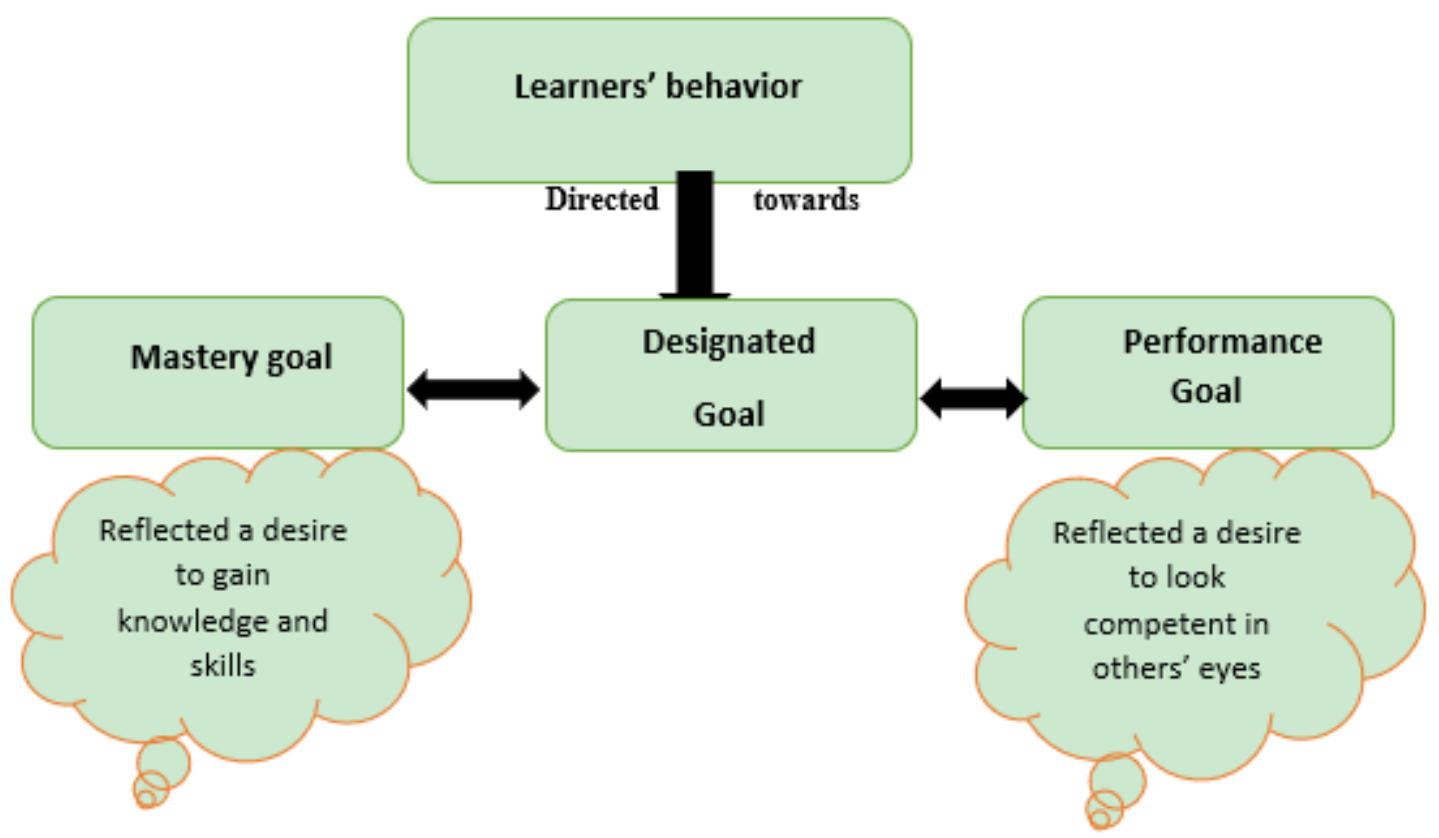

Figure 2. The Cognized Goal Theory

\subsection{Affective Processes}

Learners' belief in their capabilities affects how much stress and depressions they experience in stressful situations (Bandura, 2010). Perceived self- efficacy to exercise control plays a central role in anxiety arousal in any learning environment. So, learners who believe in their abilities to control threats do not conjure up disturbing patterns, but learners who believe they cannot manage threats experience high anxiety arousal to accomplish the learning tasks. So, perceived coping self-efficacy regulates avoidance behavior (Perkins-Gough, 2013). The stronger the sense of self-efficacy, the bolder learners are in taking on different learning activities. The kind of anxiety arousal is influenced by perceived coping efficacy to control disturbing thoughts. The perceived self- efficacy to control thought processes is the key tool in regulating thought produced stress (Bandura, 1986, 2010). The body of research stated that guided mastery is a powerful tool for instilling a robust sense of coping efficacy in learners whose functioning is impacted by the fear of self- protective reactions. Coping tasks are broken down into subtasks of easily mastered steps within sufficient time. It is a tool that teachers can utilize to create more perceived self-efficacy effects with their students. The stronger the perceived selfregulatory efficacy, the more successful learners are in integrating proper learning habits into a healthy lifestyle.

\subsection{Selection Processes}

People are partly the product of their environment. Therefore, learners' self-efficacy can shape the course of actions in any educational setting (Burnette et al., 2013). Learners resist activities and situations, they believe they exceed their coping capacities. The factors that influence choice behavior can profoundly impact the direction of learners' persona 
(Bandura, 2010). The higher the level of learners' self-efficacy, the more extensive the range of activities involvement they will consider. The higher their interest in them, the better they prepare themselves educationally to pursue their choices and their success. The task of creating a classroom learning environment conducive to the development of cognitive skills depends heavily on teachers' self-efficacy (Schwarzer, 1992; Rayan, \& Deci, 2000). Thence, teachers who have a high sense of efficacy about their teaching abilities can motivate student's cognitive development, and teachers who have a low sense of instructional efficacy relies heavily on the negative sanctions in classrooms. Therefore, both personal and communal factors are important catalysts with self-efficacy effectiveness in the learning environment. Using end of task reflection deems an effective tool to build learners self- efficacy by exploring the following questions: "Was it appropriate for me", and "Do I believe what is stated in the lesson?". This stage is a crucial stage with the learners' selfefficacy construction. However, teacher's assistance is necessarily important with improving learners' learning skills and self-efficacy endorsement.

Teachers work collectively in an interactive school social system. The staff belief system creates school cultures that can vitalize or demoralize the effects on how the school functions as a social system in societies. Schools in which staff members evaluate their skills as being capable of promoting academic success in school promote academic attainments regardless of their students' academic competencies (Wood \& Bandura, 1989; Martin, \& Dowson, 2009). This teaching approach impacts students' learning attitudes (Ormrod, 2006). Students' received instruction directs their self-efficacy towards achieving their learning goals. Consequently, classroom structures affect the development of students' intellectual self-efficacy by the relative emphasis they place on a social comparison versus self-comparison appraisal (Rayan, \& Deci, 2000; Darling-Hammond, 2018). Through a monolithic classroom structure, students rank themselves according to their learning abilities. However, through personalized classroom structures, individualized instruction tailored to student's knowledge and skills enables all students to expand their competences (Darling-Hammond, 2018). To this end, teachers' preparation, offered assistance to students, and reflections opportunities after each learning task could activate students' efficacy that notably offers a distinct contribution to the learning environment.

Overall, students are more likely to compare their rate of progress to their standards than to the performance of other colleagues. This kind of self- comparison of improvement raises perceived abilities towards the learning goals. In the same vein, cooperative learning structure in which students work together to achieve different learning tasks tends to promote a more positive self- evaluation of higher academic attainment than individualistic ones (Kunter, 2013). To this end, the process of creating students' self-efficacy starts with teachers' efficacy as they develop their course contents in a way to promote students' engagement, motivation, and self-regulation for more growth mindset learners who approach the learning with grit.

\section{Grit and Growth Mindset Towards Self- Efficacy}

The goal of positive education is to improve not only students' well-being but also their academic performance (Motz et al., 2017). A growth mindset, though, is an essential concept in this positive and productive education. It refers to the assumptions about the malleability of a person's intellectual abilities (Reeve, \& Jang, 2006; Schunk, Meece, \& Pintrich, 2014). The mindset alteration can impact the school engagement due to enhancing its students' self-efficacy (Seligman et al., 2009; Frenzel, Goetz, Lu "dtke, Pekrun, \& Sutton, 2013; Kern et al., 2016). In literature, one of the benefits of positive education is to provide students with the tools to increase their life satisfaction and nurturing their creativity (Kern et al., 2015). When teachers make use of their preparation, provide proper assistance as instructing, and help students to reflect on their learning, they manage facilitating their students' thinking skills and self-efficacy capacities.

Students come to the learning setting with various mindsets (See Table 2). To create a life- long learner, teachers ought to work on enhancing their students' growth mindset (Dweck, 2006; Heller et al., 2018). This required mindset is the core assumption about the malleability of those students' personal qualities (Yeager, \& Dweck, 2012). Yeager and Dweck (2012) reported that fixed mindset students see their intellectual abilities as something fixed and unchangeable. On the other hand, growth mindset students see their intellectual abilities as something that could be grown and developed over time. Students' mindsets make them perceive their academic work differently. The growth mindset promotes resilience, yet a fixed mindset does not (Pauli, O'Reilly, Yarkoni, \& Wager, 2016). Growth mindset students interpret pitfalls and challenges as practical approaches for more improvement with their abilities, experience, and intelligence, which increases their perseverance as learning proceeds.

The construct of grit and mindset has brought much attention among educators who seek their students' academic development. The purpose of education is to prepare students for their future life. To this point, educators seek to shape students' non-cognitive skills to impact learners' life outcomes positively. Datu, Yuen, and Chen (2017) reported that grit and growth mindset are two related variables in terms of sustained efforts. Shaping a growth mindset leads learners to develop grit and enhance their self-efficacy towards academic and personal growth (Pauli et al., 2016). 
Table 2. Learners' academic mindsets

Construct Definition

Growth mindset

(Dweck, 2006)

Grit/ Perseverance

(Duckworth et al., 2006)

Self-efficacy (Bandura, 2010)

Mastery goal orientation

(Roberson, 2013)

Sense of belonging

(Farrington, et al. 2012)

Personal Relevance

(Dweck, 2006)

Self- determination

(Ryan \& Deci 2000)
- Leamers believe that their basic abilities can be developed through the hard work and

consistent efforts. This attitude Create a sense of the love of learning and resilience.

-Learners consistently followed their goals with passion

and perseverance.

- Learners believe in their capacities to produce the designated

level of performance that could influence their lives.

- Leamers have the purpose of their growth which could guide them to some

achievement-related behaviors and task- engagement.

- Leamers create a sense that they have the rightful place in a given academic setting

and can be full membership in the learning community

-Leamers' perceptions of what is interesting and worth knowing.

-The condition that supports the leamer's experience of autonomy, competence, and relatedness. It fosters leamers' motivation and engagement for activities and tasks, so

performance, persistence, and creativity could be promoted.

\section{Teacher Efficacy}

Teachers are the life force of any educational system, and teachers' efficacy is a tool for empowering and enhancing the teaching practices. Teachers' efficacy is the beliefs about teaching effectiveness (. Abernathy-Dyer, Ortlieb, Cheek, 2013). It emphasizes a variety of essential and effective instructional decisions that could shape students' educational experiences (Soodak, \& Podell, 1997; Schriver \&, Czerniak, 1999; Lin, 2015). Bandura (1997) proposed that teachers' sense of efficacy impacts both the kind of environment that they create as well as their judgments regarding the different tasks presented in the classroom for more students' learning progression. Thus, teachers' efficacy appears to have a direct influence on teaching practices and students' learning outcomes. It has been found that teachers' self-efficacy has a considerable impact on student performance, the adoption of instructional innovation, and classroom management (Ghaith \& Shaaban, 1999; Woolfolk \& Murphy, 2001). This teaching self-efficacy enhances the teaching enthusiasm in a variety of classroom environments (Hattie, 2009).

\section{Teacher's Enthusiasm (Conceptualization and Significance for Students' Performance)}

Teacher' s enthusiasm reflects the affective part of the teacher' s motivational orientation (Kunter, 2013). Teacher's enthusiasm is the affective teaching orientation that comprises the excitement, enjoyment, and pleasure associated with both subject matters and teaching activities (Kunter et al., 2011). There are two dimensions for teacher's enthusiasm: Subject-specific enthusiasm and teaching enthusiasm. The recognition of these two dimensions facilitates what teachers are enthusiastic about. Kunter and colleagues (2011) defined the enthusiasm for teachers' subjects as enjoyment related to the activity of teaching a specific subject. This construct concerns a person- object relation. The object is the interaction with students when teaching the contents. The body of research indicates that teachers' enthusiasm is significant for 
students' learning (Keller et al., 2013; Keller et al., 2014). First, teacher's enthusiasm could increase students' attention as enthusiasm elements such as body movement and gestures reportedly catch students' attention (Bettencourt, 1983; Hilgard, 1975; Hatfield, 1993; Frenzel et al., 2013). Secondly, students may adopt the enthusiastic behavior of their teachers who served as models (Frenzel et al., 2013). Thirdly, students could be infected by their teacher' s enthusiasm and subsequently feel enthusiastic themselves (Brigham, 1992). However, it is also noted that students' enthusiasm may increase or impair students' inclusiveness in the learning process (Lacey \& Scull, 2015). To this end, teachers' enthusiasm arouses both students' learning motivation and inclusion in the learning processes.

\section{Teachers Self-efficacy and Inclusion}

Inclusiveness implementation in the classroom is always a challenge for teachers. For example, teachers of students with special needs and cultural and linguistically diverse backgrounds are required to handle numerous difficulties in their daily practice (Westwood, 2013; Shah, Das, Desai, \& Tiwari, 2016). Therefore, teachers' frequent follow-up consultations with professionals and regular meetings with stakeholders are required to tackle the various teaching and learning obstacles. There is an emphasis on inclusion education training for teachers to enhance their capabilities to face the challenges in their classrooms for more effective teaching (Florian \& Rouse, 2009; Sharma, Forlin, \& Loreman, 2008).

Teachers should have some important skills to enhance inclusion in classrooms. Sharm and colleagues (2012) recommended some crucial skills to enhance teachers' work towards class inclusion: First, clear instruction should be communicated to learners. Teachers should attend additional training for more self-efficacious and fully capable of delivering the required instructions. Secondly, inclusion education demands more collaboration of educators within the same educational setting (Ainscow \& Sandill, 2010). Thirdly, intervention strategies could be conducted to improve and manage students' behavior in classrooms (Virues-Ortega, Julio, \& Pastor-Barriuso, 2013). However, teachers should secure enough time to implement the intervention strategies to master the skills of handling their students (Forlin, Sharma, \& Loreman, 2013; Park, Dimitrov, Das, \& Gichuru, 2014). Inclusive education training should be more focused on tasks that address areas where teachers feel less efficacious (Malinen et al., 2013).

\section{Inclusive Teaching Efficacy}

There is a great positive impact of training courses of teachers' education programs on inclusive teaching efficacy (Forlin, Loreman, \& Sharma, 2014; Sharma \& Sokal, 2015). Sokal et al. (2013) proposed that student teachers attend practicum coursework to achieve higher efficacy scores than those who did only their coursework. Forlin et al. (2014) reported noticeable improvements in the efficacy of using inclusive instructions attending a system-wide professional training program in Hong Kong. Therefore, it is highly recommended to include inclusive teaching- efficacy training as a part of the core curricula of the teachers' education programs. These training programs work towards enhancing teaching efficacy in both the physical and online classrooms.

\section{Teaching Relevance}

There is a large body of evidence regarding the relative teaching methods' effectiveness. Overall, several studies indicate the importance of making teaching relevance. Ormord (2006) defined relevance as the perception that something is interesting and worth knowing. When a teacher provides relevant content for students, he/ she helps those students perceive the content as interesting and worth knowing the source of knowledge. Wilson and Sperber (2004) proposed that the feeling of relevance is the primary human feature of cognition. To this point, teachers tap into students' cognition by providing relevant knowledge. Relevance is essential for learning and teaching, as it is directly related to students' engagement and motivation. Educators attempt adding relevance to their selected content by making it enjoyable through the used activities such as games or integrating technology in their lessons' plans. This may attract learners' attention, yet if the content is not well explained to students, their attention will likely wane. Learners most likely remember the teaching activities and forget the content. In the teaching setting, relevance should draw students' attention as they realize that the content is worth knowing. So, their attention and engagement will be secured, respectively.

\subsection{Building Relevance}

There are two fundamental principles to provide relevance for students: Utility value and Relatedness. Firstly, the utility value is an academic emphasis on the importance of the utilized content for students' future goals (Ormord, 2006). Utility value provides relevance by piquing learners' interest as telling them that the content is essential to their future goals and fits into their plans. This could help learners realize that the content is not just an exciting source of knowledge but also worth knowing. Secondly, Relatedness is the tool through which learners feel that the discussed content is significantly close to their lives (Ryan \& Deci, 2000; Jones, 2017; Mahler, Großschedl, \& Harms, 2017). In this respect, the body of research emphasizes two dimensions: The nonacademic and Academic. The non-academic side of relatedness stresses the teachers' relationship with students. Teachers need to understand the different needs of students to meet them throughout the designed instruction (Ryan \& Deci, 2000; Tendhar, Singh, Jones, 2017). Students value what a likable teacher shares, 
seeing it as something worth learning. To this point, teachers' enthusiasm during the instruction process is important as it shows learners how related the content is to the instructor. The academic relatedness helps students see how current learning content relates to their knowledge and future learning. This teaching trend encourages students to see that the content is worth knowing by showing how it fits into their current and future reference framework. Thus, teachers can help students discover that what content is about could be interesting and worth knowing.

\section{Teaching Guidelines}

In the light of research on motivation, self-efficacy, and Relevance, there are some teaching guidelines for more effective teaching and learning across different disciplines:

1-Teachers should share a group of activities that help learners be competent (perceive that they are good at specific tasks), autonomy (they have the choice and control over their actions), and have relatedness (they are connected with others through positive relationships). Needs for competence, autonomy, and relatedness are the pillars of creating both intrinsic and extrinsic motivation in the learning process.

2-Teachers could tackle some behaviors in their classroom teaching for more students' autonomy in learning. Reeve and Juang (2006) reported some effective teacher' s behaviors for more students' autonomy support during the learning processes such as careful listening and providing more opportunities for improvement (see Table 3).

Table 3. Teacher's autonomy supportive behaviors

- Listen carefully to students' contributions without being judgmental.

- Create time for independent work.

- Give more opportunities to talk.

- Acknowledge signs of improvement and mastery in various discussed tasks.

- Encourage students' efforts.

- Offer help when students seemed stuck.

- Be responsive to students' comments and questions.

- Acknowledge students' related task experiences and perspectives.

- Provide students enough time to work on their tasks.

3-Teachers ought to be realistic with their delivered feedback. Teachers' feedback should attribute the learning outcomes to efforts and strategy use and not to students' aptitude, general abilities, or smartness. In doing so, teachers let students attribute their failure to controllable and unstable causes. To this point, teachers help students not to generate a feeling of helplessness during the learning and create a sense of resilience in the face of failure instead.

4-Enhancing intrinsic motivation: It is vital to support students' intrinsic motivation as it is the tool for more self-efficacy and self- determination. Teachers could provide the used incentive rewards in an informational format, such as praising students' excellent performance. Consequently, students could experience the intrinsic motivation that enhances their competence along with their learning progression.

5- Teachers can follow the MUSIC model of motivation suggested by Jones (/2009/2017). The model is used as a guide for teachers to select strategies that could increase students' motivation and engagement during the course of teaching and learning. It offers some effective guidelines to guide the instructional design. The Model comprises five main stages: Empowerment, Usefulness, Success, Interest, and Caring (See Figure 3). Therefore, teachers need to assure their students: First, feel empowered by having the ability to make decisions about their learning aspects. Second, understand why the selected contents are useful and related to their recent or future needs. Third, believe they can succeed if they put forth efforts and be strategic thinkers. Fourth, be interested in the selected contents and instructional activities. Fifth, believe that the learning environment is the tool for more constant and positive attitudes of learning and teaching in classrooms. 


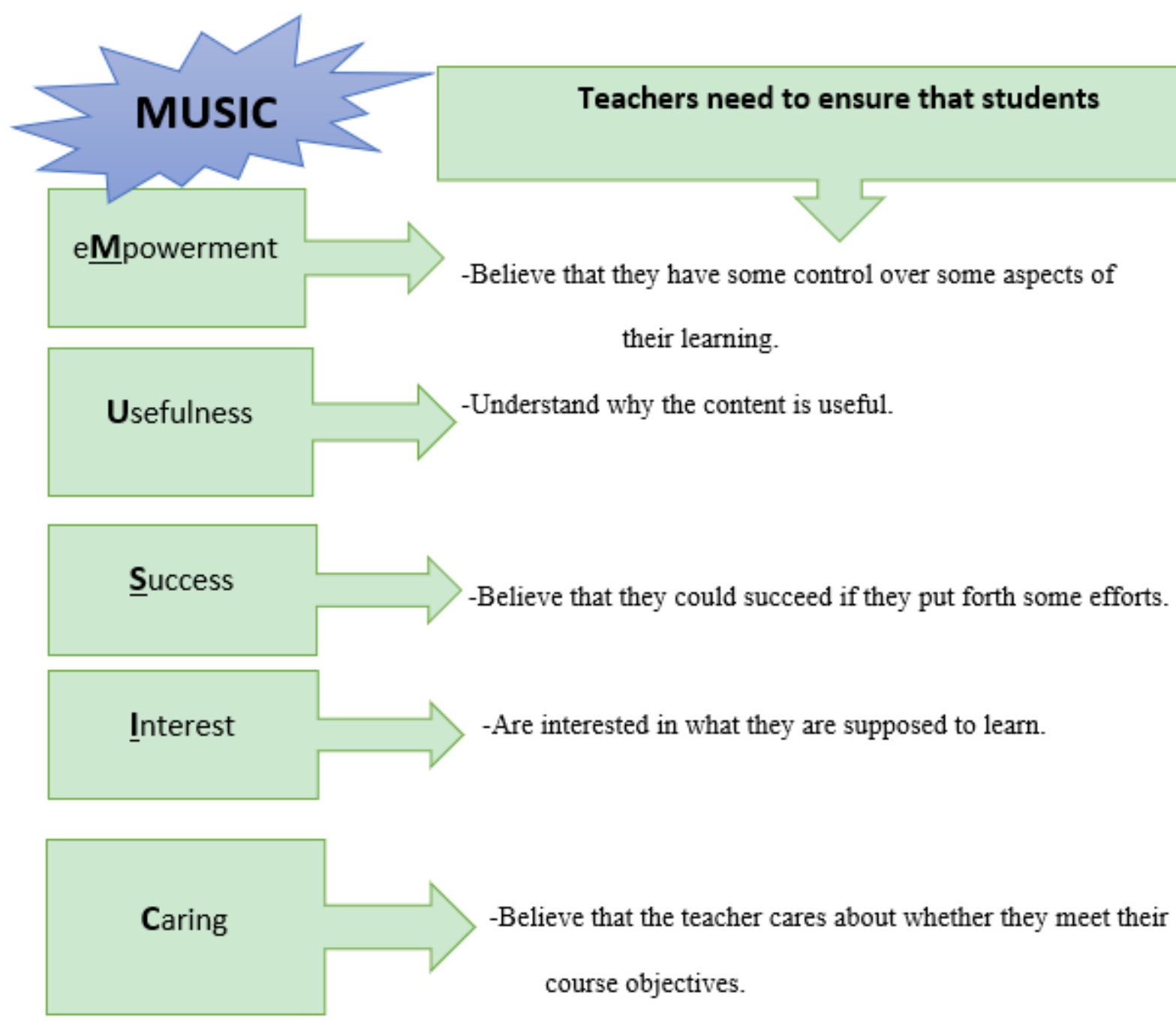

Figure 3. MUSIC Model of Academic Motivation

5-Teachers can conduct a short survey before the start of classes. Throughout this survey, they provide students with a list of activities that are likely to be in-class sequence and ask students to rank or order these suggested activities in terms of novelty, familiarity, relevance with the course and syllabus, and usefulness in their future career. Based on the results of the survey, teachers could start the semester with the most useful and meaningful part for the learners and then moves gradually to the less meaningful ones. However, teachers ought to remind students along the teaching course of the importance and value of the less significant components. Such a strategy enhances students' coping potential and increases those students' interests of in-class activities. It also shifts teachers' focus from the product-oriented task to processoriented teaching.

6-Teaching for relevance activities: In order to provide students with relevance, teachers can utilize various teaching methods to increase students' relatedness in learning the offered contents. By focusing on relatedness, teachers could provide utility value. The body of research on motivation and self-efficacy raised various activities teachers can utilize in their classrooms for more teaching relevance:

\section{A: Classroom introduction (Relatedness activity)}

The teacher should make time out of the first day of classes to learn a little about students. The teacher should share his/ her passion for the subject (a tool for sharing enthusiasm). He/ She can raise the following question during the discussion: What is the goal, aspiration, and dreams of attending this course? (Interest and utility value). Students could share their reasons for attending this particular course. On the flip side of the talk, the teacher could share related ideas about himself/ herself, so students realize that the teacher is human and approachable.

\section{B-Students' input activity (Relatedness activity)}

It is an excellent opportunity during discussions or at the end of each lesson segment to provide students with the chance 
to reflect either orally or written. The process of sharing ones' perceptions is a great tool for enhancing the relatedness and utility value in classrooms. Teachers could send the class materials to students ahead of the class meeting so that they can be familiar with the discussed issues. Also, teachers can ask students to write one or two reflection paragraphs (or more based on the class level and students' progress). Within this reflection assignment, students could relate the content to the personal experience. By providing this opportunity, students could process the content information on a deeper level. To assure students' interaction with the materials, the due date of the reflection paper could be ahead of the class meeting to get more insights into students' ideas for more teaching guidance. Moreover, using the forum could be an excellent opportunity to share students' reflections. It is a way of gaining much more in-depth insights into the raised issues and used contents.

\section{Conclusion}

Classrooms are highly organized social and cultural learning environments. Social, interactional, and organizational processes provide learners with the socio-cultural factors influencing those learners' academic and personal development as well as paving the way for understanding one's learning capacities. The perceived self-efficacy is concerned with people's belief in their capabilities to practice control over the events that could affect their lives and their functioning. Countless studies have documented the wide-range benefits of self-efficacy concerning self-regulation. Existing theories suggest that learners' perceptions of effort shape deteriorating self-efficacy. Therefore, one way to pertain selfefficacy is to cultivate a growth mindset, which has shown to impact behaviors in part by altering effort attributions. The given trait could be improved through practice. Research indicates that a growth mindset of self-efficacy can change attributions and allocations of effort in meaningful ways that could impact the learners' willingness to attempt challenging tasks and required perseverance to complete the designated tasks.

Perceived self-efficacy is concerned with people's belief in their capabilities to exercise control ov er their functioning and events that could influence their lives. Self-efficacy affects life choices, level of motivation and functioning quality, and resilience with the learning failures. Four main sources of influence develop Self-efficacy beliefs: Mastery experience, experience the success of other people with similar tasks, social persuasion that one has the capabilities for success, and inferences from somatic states that indicate personal strengths. Learners need self-efficacy to sustain their task perseverant effort for success. All in all, learners' self-efficacy regulates how they participate in learning processes and guides teachers to motivate those learners to act in class effectively and energetically. Hence, students are active interpreters of learning tasks and activities considering their salient self-structures in their minds as goalorientation, self-efficacy, relevance, mastery of learning activities, interests, and control over the learning processes.

\section{References}

Abernathy-Dyer, J., Ortlieb, E., \& Cheek, E. H. (2013). An analysis of teacher efficacy and perspectives about elementary literacy instruction. Curr Issues Educ., 16(3),1-14.

Ainscow, M., \& Sandill, A. (2010). Developing inclusive education systems: The role of organizational cultures and leadership. International Journal of Inclusive Education, 14(4), 401e416. https://doi.org/10.1080/13603110802504903

Bandura, A. (1986). Social foundations of thought and action: A social cognitive theory. Englewood Cliffs, NJ: PrenticeHall.

Bandura, A. (1991a). Self-efficacy mechanism in physiological activation and health-promoting behavior. In J. Madden, IV (Ed.), Neurobiology of learning, emotion, and affect (pp. 229-270). New York: Raven.

Bandura, A. (1991b). Self-regulation of motivation through anticipatory and self-regulatory mechanisms. In R. A. Dienstbier (Ed.), Perspectives on motivation: Nebraska symposium on motivation (Vol. 38, pp. 69-164). Lincoln: University of Nebraska Press.

Bandura, A. (1997). Self-efficacy: The exercise of control. New York: Freeman.

Bandura, A. (2010). "Self-Efficacy." The Corsini Encyclopedia of Psychology Ed. Irving B. E and W. Edward Craighead (4th ed.). Hoboken, NJ: Wiley, 2010. 1534-1536. Gale Virtual Reference Library Web. Retrieved 7 Oct. 2016.

Bettencourt, E. M., Gillett, M. H., \& Damien Gall, M. (1983). Effects of teacher enthusiasm training on student on- task behavior and achievement. Am Educ Res J., 20(3), 435-450. https://doi.org/10.3102/00028312020003435

Brigham, F. J., Scruggs, T. E., \& Mastropieri, M. A. (1992). Teacher enthusiasm in learning disabilities classrooms: Effects on learning and behaviour. Learn Disabil Res Pract., 7, 68-73.

Burnette, J. L., O’Boyle, E. H., VanEpps, E. M., Pollack, J. M., \& Finkel, E. J. (2013). Mind-sets matter: a meta-analytic review of implicit theories and self-regulation. Psychol. Bull., 139, 655-671. https://doi.org/10.1037/a0029531 
Darling-Hammond, L. (2000). Teacher quality and student achievement. Educ Policy Anal Arch., 8(1), 1-44. https://doi.org/10.14507/epaa.v8n1.2000

Datu, J., Yuen, M., \& Chen, G. (2017). Grit and Determination: A Review of Literature with Implications for Theory and Research. Journal of Psychologists and Counsellors in Schools, 27(2), 168-176. https://doi.org/10.1017/jgc.2016.2

Dockter, D., Uvarov, C., Guzman-Alvarez, A., \& Molinaro, M. (2017). Improving preparation and persistence in undergraduate STEM: why an online summer preparatory chemistry course makes sense. In: Sorensen PM, Canelas DA, editors. Online Approaches to Chemical Education. Washington: DC, American Chemical Society (pp733). https://doi.org/10.1021/bk-2017-1261.ch002

Duckworth, A. L., \& Seligman, M. E. P. (2006). Self- discipline gives girls the edge: Gender in self-- discipline, grades, and achievement test scores. Journal of Educational Psychology, 98(1), 198-208. https://doi.org/10.1037/00220663.98.1.198

Dweck, C. S. (2006). Mindset: The New Psychology of Success. New York: Ballantine Books.

Farrington, C. A., Roderick, M., Allensworth, E., Nagaoka, J., Keyes, T. S., Johnson, D. W., \& Beechum, N. O. (2012). Teaching adolescents to become learners. The role of noncognitive factors in shaping school performance: A critical literature review. Chicago: University of Chicago Consortium on Chicago School Research

Florian, L., \& Rouse, M. (2009). The inclusive practice project in Scotland: Teacher education for inclusive education. Teaching and Teacher Education, 25(4), 594e601. https://doi.org/10.1016/j.tate.2009.02.003

Forlin, C., Loreman, T., \& Sharma, U. (2014). A system-wide professional learning approach about inclusion for teachers in Hong Kong. Asia-Pacific Journal of Teacher Education, 42(3), $247 \mathrm{e} 260$. https://doi.org/10.1080/1359866X.2014.906564

Forlin, C., Sharma, U., \& Loreman, T. (2013). Predictors of improved teaching efficacy following basic training for inclusion in Hong Kong. International Journal of Inclusive Education, 18(7), $718 \mathrm{e} 730$. https://doi.org/10.1080/13603116.2013.819941

Frenzel, A. C., Becker-Kurz, B., Pekrun, R., \& Goetz, T. (2017). Teaching this class drives me nuts! Examining the person and context specificity of teacher emotions. PLoS One, 10(6), e0129630. https://doi.org/10.1371/journal.pone.0129630

Frenzel, A. C., Goetz, T., Lu "dtke, O., Pekrun, R., \& Sutton, R. E. (2013). Emotional transmission in the classroom: Exploring the relationship between teacher and student enjoyment. J Educ Psychol., 101(3), 705-716. https://doi.org/10.1037/a0014695

Ghaith, G., \& Shaaban, K. (1999). The relationship between perceptions of teaching concerns, teacher efficacy, and selected teacher characteristics. Teaching and Teacher Education, 15, 487-496. https://doi.org/10.1016/S0742051X(99)00009-8

Hall, S., Jones, B. D., Amelink, C., \& Hu, D. (2013). Educational innovation in the design of an online nuclear engineering curriculum. J Effect Teach., 13, 58-72.

Hatfield, E., Cacioppo, J. T., Rapson, R. L. Emotional contagion. Curr Dir Psychol Sci., 2(3), 96-99. https://doi.org/10.1111/1467-8721.ep10770953

Hattie, J. (2009). Visible learning: A synthesis of over 800 meta-analyses relating to achievement. London: Routledge. 2009. The relationship between teachers' self-efficacy and enthusiasm and students' performance. PLOS ONE. https://doi.org/10.1371/journal.pone.0207252

Heller, K. A., Perleth, C., Kognitiver, Fa, "higkeitstest fu “r 4. bis 12. Klassen, Revision: KFT 4-12+ R. Weinheim: BeltzTest; 2000. German. The relationship between teachers' self-efficacy and enthusiasm and students' performance. https://doi.org/10.1371/journal.pone.0207252

Hilgard, E. R., Atkinson, R. C., \& Akinson, R. L. (1975). Introduction to psychology (6th ed). New York: Harcourt Brace Jovanovich.

Jone, B. D. (2009). Motivating students to engage in learning: The Music Model of Academic Motivation. International Journal of Teaching and Learning in Higher Education, 21(2), 272-285.

Jones, B. D. (2017). User Guide for Assessing the Components of the MUSIC Model of Academic Motivation. Available online at http://www.the MUSICmodel.com

Jones, B. D. (2018). Motivating Students by Design: Practical Strategies for Professors (2nd ed). Charleston, SC: CreateSpace. 
Jones, B. D., \& Skaggs, G. E. (2016). Measuring students' motivation: validity evidence for the MUSIC model of academic motivation inventory. Int J Scholarsh Teach Learn, 10, 1-9. https://doi.org/10.20429/ijsotl.2016.100107

Jones, B. D., Li, M., \& Cruz, J. M. (2017). Cross-cultural validation of the MUSIC ${ }^{\circledR}$ model of academic motivation inventory: evidence from Chinese- and Spanish-speaking university students. Int J Edu Psychol., 6, 366-385. https://doi.org/10.17583/ijep.2017.2357

Jones, B. D., Tendhar, C., \& Paretti, M. C. (2016). The effects of students' course perceptions on their domain identification,motivational beliefs, and goals. J Career Dev., 43, 383-397. https://doi.org/10.1177/0894845315603821

Keller, M. M., Goetz, T., Becker, E. S., Morger, V., \& Hensley, L. (2014). Feeling and showing: A new conceptualization of dispositional teacher enthusiasm and its relation to students' interest. Learn Instr., 33, 29-38. https://doi.org/10.1016/j.learninstruc.2014.03.001

Keller, M., Neumann, K., Fischer, H. E. Teacher enthusiasm and student learning. In: Hattie J, editor. International guide to student achievement. New York: Routledge, 247-249.

Kern, M. L., Benson, L., Steinberg, E. A., \& Steinberg, L. (2016). The EPOCH measure of adolescent well-being. Psychol. Assess. ,28, 586-597. https://doi.org/10.1037/pas0000201

Kern, M. L., Waters, L. E., Adler, A., \& White, M. A. (2015). A multidimensional approach to measuring well-being in students: Application of the PERMA framework. J. Posit. Psychol., 10, 262-271. https://doi.org/10.1080/17439760.2014.936962

Kunter, M. (2013). Motivation as an aspect of professional competence: Research findings on teacher enthusiasm. In: Kunter M, Baumert J, Blum W, Klusmann U, Krauss S, Neubrand M, editors. Cognitive activation in the mathematics classroom and professional competence of teachers. New York: Springer, 273-289. https://doi.org/10.1007/978-1-4614-5149-5_13

Kunter, M., Frenzel, A., Nagy, G., Baumert, J., \& Pekrun, R. (2011). Teacher enthusiasm: Dimensionality and context specificity. Contemp Educ Psychol., 36, 289-301. https://doi.org/10.1016/j.cedpsych.2011.07.001

Lazowski, R. A., \& Hulleman, C. S. (2106). Motivation interventions in education: a meta-analytic review. Rev Educ Res., 86, 602-640. https://doi.org/10.3102/0034654315617832

Lin, C. C. (2015). Validation of the psychological well-being scale for use in Taiwan. Soc. Behav. Pers. Int. J., 43, 867874. https://doi.org/10.2224/sbp.2015.43.5.867

Mahler, D., Großschedl, J., \& Harms, U. (2017). Opportunities to learn for teachers' self-efficacy and enthusiasm. Education Research International. 2017; Article ID 4698371. https://doi.org/10.1155/2017/4698371

Malinen, O. P., Savolainen, H., Engelbrecht, P., Xu, J., Nel, M., \& Nel, N. (2013). Exploring teacher self-efficacy for inclusive practices in three diverse countries. Teaching and Teacher Education, 33, 34e44. https://doi.org/10.1016/j.tate.2013.02.004

Martin, A. J., \& Dowson, M. (2009). Interpersonal relationships, motivation, engagement, and achievement: Yields for theory, current issues, and educational practice. Review of Educational Research, 79, 327-365. https://doi.org/10.3102/0034654308325583

McGinley, J., \& Jones, B. D. (2014). A brief instructional intervention to increase students' motivation on the first day of class. Teach Psychol., 41, 158-162. https://doi.org/10.1177/0098628314530350

Mora, C. E., Anorbe-Diaz, B., Gonzalez-Marrero, A. M., Martin-Gutierrez, J., \& Jones, B. D. Motivational factors to consider when introducing problem-based learning in engineering education courses. Int J Eng Edu., 33, 1000-1017.

Motz, B. A., de Leeuw, J. R., Carvalho, P. F., Liang, K. L., \& Goldstone, R. L. (2017). A dissociation between engagement and learning: Enthusiastic instructions fail to reliably improve performance on a memory task. PloS One, 12(7), e0181775. https://doi.org/10.1371/journal.pone.0181775

Ormrod, J. E. (2006). Educational psychology: Developing learners (5th ed.). Upper Saddle River, N.J.: Pearson Education, Inc.

Pajares, F. (1996). Self-efficacy beliefs and mathematical problem-solving of gifted students. Contemp Educ Psychol., 21(4), 325-344. PMID: 8979868. https://doi.org/10.1006/ceps.1996.0025

Park, M., Dimitrov, D. M., Das, A., \& Gichuru, M. (2014). The teacher efficacy for inclusive practices (TEIP) scale: Dimensionality and factor structure. Journal of Research in Special Educational Needs, 16(1), 2e12. https://doi.org/10.1111/1471-3802.12047 
Pauli, W. M., O’Reilly, B. C., Yarkoni, T., \& Wager, T. D. (2016). Regional specialization within the human striatum for diverse psychological functions. Proceedings of the National Academy of Sciences of the United States of America, 113(7), 1907-1912. https://doi.org/10.1073/pnas.1507610113

Perkins-Gough, D. (2013). The significance of GRIT: a conversation with Angela Lee Duckworth. Educational Leadership, 71(1), 14-20.

Reeve, J., \& Jang, H. (2006). What teachers say and do to support students' autonomy during a learning activity. Journal of Education Psychology, 98(1), 209-218. https://doi.org/10.1037/0022-0663.98.1.209

Roberson, R. (2013). Helping students find relevance. Psychology Teacher Network. Retrieved September 13, 2016, from http://www.apa.org/ed/precollege/ptn/2013/09/students-relevance.aspx

Ryan, R., \& Deci, E. (2000). Self- determination theory and the facilitation of intrinsic motivation, social development, and well-being. American Psychologist, 55 (1), 68-78. https://doi.org/10.1037/0003-066X.55.1.68

Schriver, M. C., \& Czerniak, C. M. (1999). A comparison of middle and junior high school teachers' level of efficacy and knowledge of developmentally appropriate curriculum and instruction. J Sci Teacher Educ., 10(1), 21-42. https://oi.org/10.1023/A:1009472629345

Schunk, D. H., Meece, J. L., \& Pintrich, P. R. (2014). Motivation in Education: Theory, research \& Application. Upper Saddle River, NJ: Pearson.

Schwarzer, R. (Ed.). (1992). Self-efficacy: Thought control of action. Washington, DC: Hemisphere.

Shah, R., Das, A., Desai, I., \& Tiwari, A. (2016). Teachers' concerns about inclusive education in Ahmedabad, India. Journal of Research in Special Educational Needs, 16(1), 34e45. https://doi.org/10.1111/1471-3802.12054

Sharma, U., Forlin, C., \& Loreman, T. (2008). Impact of training on pre-service teachers' attitudes and concerns about inclusive education and sentiments about persons with disabilities. Disability \& Society, 23(7), 773e785. https://doi.org/10.1080/09687590802469271

Sharma, U., Loreman, T., \& Forlin, C. (2012). Measuring teacher efficacy to implement inclusive practices. Journal of Research in Special Educational Needs, 12(1), 12e21. https://doi.org/10.1111/j.1471-3802.2011.01200.x

Sokal, L., Woloshyn, D., \& Funk-Unrau, S. (2013). How important is practicum to preservice teacher development for inclusive teaching? Effects on efficacy in classroom management. Alberta Journal of Educational Research, 59(2), 285e298. Retrieved from http://www.ajer.ca/

Soodak, L. C., \& Podell, D. M. (1997). Efficacy and experience: Perceptions of efficacy among preservice and practicing teachers. Journal of Research and Development in Education, 30(4), 214-221.

Tendhar C, Singh K, \& Jones, B. D. (2017). Using the domain identification model to study major and career decisionmaking processes. Eur J Eng Edu., 43, 235-246. https://doi.org/10.1080/03043797.2017.1329280

Virues-Ortega, J., Julio, F. M., \& Pastor-Barriuso, R. (2013). The TEACCH program for children and adults with autism: A meta-analysis of intervention studies. Clinical Psychology Review, 33(8), 940e953. https://doi.org/10.1016/j.cpr.2013.07.005

Westwood, P. (2013). Inclusive and adaptive teaching: Meeting the challenge of diversity in the classroom. Oxford, UK: Routledge. https://doi.org/10.4324/9780203069806

Wood, R. E., \& Bandura, A. (1989). Social cognitive theory of organizational management. Academy of Management Review, 14, 361-384. https://doi.org/10.5465/amr.1989.4279067

Woolfolk Hoy, A., \& Murphy, P. K. (2001). Teaching educational psychology to the implicit mind. In B. Torff \& R. Sterberg (Eds.), Understanding and teaching the intuitive mind (pp. 145-185). Mahwah, NJ: Erlbaum.

Yeager, D. S., \& Dweck, C. S. (2012). Mindsets that promote resilience: when students believe that personal characteristics can be developed. Educ. Psychol., 47, 302-314 https://doi.org/10.1080/00461520.2012.722805

\section{Copyrights}

Copyright for this article is retained by the author(s), with first publication rights granted to the journal.

This is an open-access article distributed under the terms and conditions of the Creative Commons Attribution license which permits unrestricted use, distribution, and reproduction in any medium, provided the original work is properly cited. 